\title{
IV Utilization or Access by Licensed Athletic Trainer in the Clinical Setting
}

\author{
Benito J. Velasquez, DA, LAT, ATC* \\ Athletic Training Department, School of Allied Health, Lincoln Memorial University, 6965 Cumberland Gap Parkway, Harrogate, TN, USA
}

\section{"Corresponding author}

Benito J. Velasquez, DA, LAT, ATC

Program Director/Chair, Athletic Training Department, School of Allied Health, Lincoln Memorial University, 6965 Cumberland Gap Parkway, Harrogate, TN 37752, USA; E-mail: benito.velasquez@LMUnet.edu

\section{Article information}

Received: February 28 ${ }^{\text {th }}$, 2018; Accepted: March 6 ${ }^{\text {th }}, 2018$; Published: March 6 ${ }^{\text {th }}, 2018$

\section{Cite this article}

Velasquez BJ. IV utilization or access by licensed athletic trainer in the clinical setting. Sport Exerc Med Open J. 20I8; 4(I): el-e3. doi: I0. I7I40/SEMOJ-4-e004

$\mathrm{I}^{\mathrm{n}}$

magine being out at a sports practice, it's hot and humid and the team is in its preseason conditioning program. One of your athletes observes profuse sweating, dizziness, decreased motor function. In addition, this athlete has a history of sickle-cell trait and is starting to cramp in their lower extremities. We remove them from practice and move them to a cool indoor environment. We start administering oxygen and activate our emergency action plan (EAP) and called emergency medical services (EMS), but it will be 20 minutes or so to travel to the campus. What else can we do? We apply ice bags to the lower extremities, we cool the athlete and administer water and electrolytes orally and we wait and wait until EMS gets there.

Further action WE could do is initiate an IV on this patient.

The new Commission on Accreditation of Athletic Training Education (CAATE) Standards ${ }^{1}$ are out regarding what skills athletic training students will need to be taught in preparation for being a certified athletic trainer. Some of the skills include teaching our student how to suture wounds, perform blood draws, perform subcutaneous injections, and administration of an intravenous (IV), and/or establish IV access. Specific to the CAATE document, are standards 70 and 75, which is part of the patient/client care section, with the subsection "Examination, Diagnosis, and Intervention" of the core competencies. Standard 70 states: "Evaluate and mange patient with acute conditions, including triaging conditions that are life threatening or otherwise emergent' ${ }^{1}$ Under this standard, the care of life threatening conditions such as exertional sickling, rhabdomyolysis and other heat related conditions, may warrant prehospital IV access and fluid therapy., ${ }^{2,3}$ In addition, Standard 75, states "Administer medications or other therapeutic agents by the appropriate route of administration upon the order of a physician or other provider with legal prescribing authority" which would be specific to the administering of an IV or IV access as a therapeutic agent and the IV and/or IV access would be an "appropriate route of administration" of fluids or medications. ${ }^{1}$

This paper will address the utilization of IV and/or IV access by athletic trainers in the clinical setting. Utilization of IV and/or establishing IV access is a skill any licensed athletic trainer can learn. Implementation can become part of the emergency action plan (with physician approval and following established state practice acts) in the clinical setting.

\section{REVIEW OF THE LITERATURE}

An intravenous IV with the insertion of an IV catheter allows a route for medication or fluids from an attached bag to be rapidly administered. ${ }^{2}$ Medications can also be injected via an attached port or from the injection of medication into the IV bag. In most cases, the IV route carries fluids to a patient for rapid rehydration and stabilizing the patient. The introduction of an IV or IV access before arrival at the hospital emergency room (ER) can prevent patient mortality. ${ }^{2,3} \mathrm{IV}$ administration is standard practice to stabilize patients in hospitals, clinics and are performed by doctors, nurses, but in the field, EMS personnel (depending on their state practice act) can administer an IV. ${ }^{3}$ An evidence-based review of the literature finds that fluids delivered orally is recommended as the firstline of rehydration for heat-related emergencies, but found evidence of both oral fluids and IV provided a more efficient patient recovery. ${ }^{4,5}$ If the patient is not able to tolerate taking fluids orally, the use of an IV should be considered. ${ }^{5}$ For treating exertional heat stroke, it's recommended that if licensed and trained personnel are available, an IV can assist with rehydration and support cardiovascular function. ${ }^{5}$ In a sickle-cell (sickling) emergency, the National Athletic Trainers' Association (NATA) - Consensus Statement on Sickle Cell Trait and the Athlete outline the medical emergency 
steps that indicate "if the athlete is obtunded or as vital signs decline, call 911, attach an AED, start an IV and get the athlete to the hospital fast'. ${ }^{6}$

There are several medical conditions that would warrant intravenous IV or IV access and improve patient care:
a. Exertional exercise cramps
b. Heat illness
c. Dehydration due to medical reasons (flu, and illnesses that dehydrate the body of fluids)
d. Environmental dehydration (lack of fluids due to availability, or related to weather conditions)
e. Sickle-cell events
f. Spinal shock
g. Trauma
h. Diabetic emergencies.

\section{WHEN IS AN IV NOT WARRANTED?}

For head traumas and concussion, IVs should not be administered, but an IV access can be. The reason fluids should not be administered is that an IV will increase the fluid in the body, and this may contribute to increased intracranial pressure. An IV access will not contribute to increasing intracranial pressure, because no fluid is being administered, the port is available should the emergency room physician need to administer fluids and medications.

\section{WHY SHOULD ATHLETIC TRAINERS ADMINISTER INTRAVENOUS IVs AND IV ACCESS?}

Athletic trainers are the front line healthcare provider for athletic injuries that occur at practices and athletic events. They already have emergency action plans to address:

a. Automated external defibrillator (AED) application and treatment of cardiac emergencies

b. Airway emergencies and the use of oral and nasal airways and use of bag valve mask and oxygen administration

c. Spinal trauma/shock immobilization techniques

d. Immobilization of fractures, sprains, and strains

e. Assessing and treating allergic reactions requiring an auto-injectable epinephrine injection

f. Assessing and treating diabetic emergencies and use of blood glucose meter

g. Assessing and treating asthma-related conditions and peak flow meters

During a medical emergency, the utilization of IV and IV access by the licensed athletic trainer can provide positive patient outcomes and treatment. The benefit of having an athletic trainer administer an IV or IV access, allows the patient to quickly receive intravenous fluids to replace lost fluids or if fluids are not indicated, the IV access is established to keep the vein open so when they get to the ER, the physician can administer the appropriate treatment. Athletic trainers trained to administer IV or IV access, are taught which medical conditions warrant immediate IV admin- istration and which conditions do not.

\section{EDUCATION REQUIREMENTS FOR AN IV TECHNICIAN —-}

According to various websites on jobs and careers, the requirements vary from state to state but may include becoming a pharmacy technician. Formal training to earn the IV certification in most cases require a high school diploma or graduate equivalency degree (GED) and the student can earn their certificate from a community college. ${ }^{7,8}$

\section{EDUCATIONAL BACKGROUND OF THE LICENSED ATHLETIC TRAINER}

All athletic trainers licensed by a state regulatory agency have at the very least, a bachelor's or master's degree and have passed a national board exam. In addition, with the new CAATE standards, this material will now be a required skill taught to future athletic trainers.

\section{STATE PRACTICE ACTS}

Athletic trainers need to be aware of their state practice acts and the scope of practice. A small number of states have in their practice act, the terminology that athletic trainers may perform any medical procedure their team physician has approved, or the team physician established a written protocol or has standing orders and this could include IV administration. ${ }^{7,9}$

\section{CONCLUSION}

In conclusion, there is no rationale to inhibit the athletic trainer from administrating an IV or IV access to a patient, provided they have the necessary training, established protocols approved by a physician and follow their state practice acts.

\section{REFERENCES |}

1. Commission on Accreditation of Athletic Training Education 2020 Standards. Published March 1, 2018; Accessed March 1, 2018.

2. Cuppett M, Walsh KM. General Medical Conditions in the Athlete. $2^{\text {nd }}$ ed. St. Louis, Missouri, USA: Mosby, Inc, an affiliate of Elsevier Inc.; 2012.

3. Seymour CW, Cooke CR, Hebert PL, Rea TD. Intravenous access during pre-hospital emergency care of non-injured patients: A population-based outcome study. Ann Emerg Med. 2012; 59(4): 296-303. doi: 10.1016/j.annemergmed.2011.07.021

4. McDermott BP, Anderson SA, Armstrong LE, et al. National athletic trainers position statement: Fluid replacement for the physically active. J Athl Train. 2017; 52(9): 877-897. doi: 10.4085/10626050-52.9.02

5. Casa DJ, DeMartini JK, Bergeron MF, et al. National athletic trainers position statement: Exertional heat illnesses. J Athl Train. 
2015; 50(9): 986-1000. doi: 10.4085/1062-6050-50.9.07

6. Anderson S, Eichner ER. Consensus Statement: Sickle Cell Trait and the Athlete. National Athletic Trainers Association. 2007. Web site. https://www.nata.org/news-publications/pressroom/statements/consensus. Accessed February 27, 2018.

7. Fuchs EJ. Athletic Trainer's Utilization \& Clinical Establishment of IV Access \& Fluid Administration to Improve Patient Care. Presented at Kentucky Athletic Trainers Society IV EBP CEU
Workshop; February 25. 2018; Richmond, KY, USA.

8. How to become an IV Technician-Study.Com. https://study. com/articles/How_to_Become_an_IV_Technician_Education_ and_Career_Roadmap.html. Accessed February 26, 2018.

9. Becoming an IV Technician Learning Path.org. Web site. http:// learningpath.org/articles/Becoming_an_IV_Technician_Salary_ Info_Job_Description.html. Accessed February 26, 2018. 